\title{
11. Work experience, the contract of employment and the scope of labour law: The United Kingdom and Australia compared ${ }^{1}$
}

\section{Rosemary Owens}

\subsection{INTRODUCTION}

The 'crisis of modern labour law' is that millions of workers are outside its protections: a situation resulting, it has been argued, not so much from an explicit embrace of extreme deregulation but from inaction in the face of two interrelated developments in the world of work, namely, the growth of the informal economy and the proliferation of new forms of work falling outside the definition of employee. ${ }^{2}$ These issues have garnered attention not only from scholars but also from governments, social partners and other stakeholders, at both the national and international levels. Their importance has been highlighted recently by the report of the ILO's Global Commission on the Future of Work and the adoption by the International Labour Conference of the Centenary Declaration for the Future of Work. ${ }^{3}$

\footnotetext{
1 The author gratefully acknowledges funding from the Australian Research Council (DP150104516: 'Work Experience: Labour Law at the Intersection of Work and Education').

2 Guy Davidov and Brian Langille, 'Introduction: Goals and Means in The Regulation of Work' in Guy Davidov and Brian Langille (eds), Boundaries and Frontiers of Labour Law (Hart 2006) 1.

3 ILO, Work for a Brighter Future: Global Commission on the Future of Work (ILO 2019), https://www.ilo.org/wcmsp5/groups/public/---dgreports/---cabinet/ documents/publication/wcms_662410.pdf, accessed 30 March 2021; ILO, 'Centenary Declaration for the Future of Work' (Adopted by the International Labour Conference, 108th session, Geneva, 21 June 2019), https://www.ilo.org/wcmsp5/groups/public/ ---ed_norm/---relconf/documents/meetingdocument/wcms_711674.pdf, accessed 30 March 2021.
} 
Thus the scope of labour law and the adequacy of its fundamental concepts to respond to the changing world of work is a focus of those engaged in policy and legal discourse. In particular, the boundary between employment and self-employment and the most effective way to regulate it remain matters of debate. ${ }^{4}$ The advent of the gig economy has attracted much recent scholarly discussion. ${ }^{5}$ However, with some notable exceptions, ${ }^{6}$ far less attention has been devoted to identifying the limits and scope of labour law in the context of the regulatory challenges posed by the intersection of education and work.

This chapter focuses on these issues. The background context is not only changes in the world of work, but also developments in the world of education. ${ }^{7}$ Universities, schools and other training institutions have been undergoing significant change. The emergence of the digital classroom and the 'Uber-fication' of education - where commercial providers deliver a wide range of courses on a global basis - is already evident. These courses may not always comply with government regulation of education, ${ }^{8}$ and there is already some evidence of multinational corporations disregarding national regulation. ${ }^{9}$ The main section of this chapter examines the common law's understanding of the intersection of education and work, in relation to unpaid work experience, internships and traineeships, in Australia and the United Kingdom (UK). ${ }^{10}$ The concluding section of this chapter is mindful of the challenge presented by the Global Commission on the Future of Work: 'to seize the opportunities presented by these transformative changes to create a brighter future and deliver

4 See Nicola Kountouris, "The Concept of "Worker" in European Labour Law: Fragmentation, Autonomy and Scope' (2018) 47 Indust LJ 192; Martin Risak and Thomas Dullinger, The Concept of 'Worker' in EU Law: Status Quo and Potential for Change (ETUI 2018).

5 See eg Abi Adams, Judith Freedman and Jeremias Prassl, 'Rethinking Legal Taxonomies for the Gig Economy' (2018) 34 Oxford Rev Econ Pol 475; Andrew Stewart and Shae McCrystal, 'Labour Regulation and the Great Divide: Does the Gig Economy Require a New Category of Worker?' (2019) 32 Aust J Lab L 4.

$6 \quad$ See Niall O'Higgins, Rising to the Youth Employment Challenge: New Evidence on Key Policy Issues (ILO 2017); Andrew Stewart, Rosemary Owens, Anne Hewitt and Irene Nikoloudakis, 'The Regulation of Internships: A Comparative Study' (2018) International Labour Office Employment Policy Department Working Paper No 240.

7 See Rosemary Owens, Andrew Stewart, Anne Hewitt and Joanna Howe, 'Labour Regulation, Work Experience and Youth: Lessons from the Scholarship of Ann Numhauser-Henning' in Mia Rönnmar and Jenny Julén Votinius (eds), Festskrift till Ann Numhauser-Henning (Lund 2017).

8 Bob Lingard, Sam Sellar, Anna Hogan and Greg Thompson, Commercialisation in Public Schooling (NSW Teachers' Federation 2017).

$9 \quad$ See Bridge International Academies (K) Ltd v Attorney-General, High Court of Uganda, Misc Application No 70 of 2018 (arising from Misc Cause No 23 of 2018).

${ }_{10}$ For a detailed analysis of the law in the USA, see Chapter 10 in this volume. 
economic security, equal opportunity and social justice - and ultimately reinforce the fabric of our societies'. ${ }^{11}$

The Global Commission identified increasing investment in people's capabilities, including 'a universal entitlement to lifelong learning that enables people to acquire skills and to reskill and upskill' and 'stepping up investments in the institutions, policies and strategies that will support people through future of work transitions', ${ }^{12}$ as a critical means to achieve the end of decent and sustainable work for all. The ILO Centenary Declaration commits to this goal. ${ }^{13}$ These strategies require regulatory action rather than inaction. This chapter suggests some of the regulatory responses needed to meet the challenges at the intersection of education and work. It considers whether any inadequacy in the capacity of the common law to regulate unpaid work experience, internships and traineeships stems from a limitation in the concepts of 'employee' and 'employment' and, to this end, it considers the purposes of labour law and their relation to its subject. ${ }^{14}$

\subsection{LABOUR LAW AT THE INTERSECTION OF WORK AND EDUCATION}

\subsubsection{Recent Australian Labour Law Cases on Unpaid Internships}

At first glance, it might be thought that in recent years common law jurisdictions have demonstrated labour law's capacity to respond to the challenge of unpaid internships and include them within its protections.

In Australia, for example, there is now a significant body of case law concerning unpaid internships where courts have imposed penalties on employers for breaches of labour law in relation to the provision of basic standards, such as minimum pay, and payments for overtime, public holidays or accrued annual leave. Persons undertaking work experience have also sometimes been protected from other harms, such as injury or sexual harassment at work. ${ }^{15}$ The cases have often involved open-market arrangements. ${ }^{16}$ In some (but by

\footnotetext{
11 ILO Global Commission on the Future of Work (n 3) 1.

12 Ibid 11.

13 ILO, 'Centenary Declaration' (n 3) esp IIA(iii), IIIA(ii)-(iv), IIIB(i)-(iv).

14 See generally Guy Davidov, A Purposive Approach to Labour Law (OUP 2016). See also Mark Freedland, The Personal Employment Contract (OUP 2003); Mark Freedland and Nicola Kountouris, The Legal Construction of Personal Work Relations (OUP 2011); Stewart and McCrystal (n 5). 221.

15 Cossich v G Rosetto and Co Pty Ltd [2001] SAIRC 37; GLS v PLP [2013] VCAT

16 Fair Work Ombudsman v Bosen [2011] VMC 81; Enforceable Undertaking given by McDonald Real Estate Dandenong Pty Ltd [5 December 2012]; Fair
} 
no means all) instances, the internship had been sought by students engaged in formal study programmes of relevance to the industry who did not formally require work experience. ${ }^{17}$ In a number of instances, unpaid work experience was undertaken for consecutive periods, as an open-market arrangement and a requirement of a course of study. ${ }^{18}$ In yet other cases, a recent graduate was taken on by a business as an intern. ${ }^{19}$

In other common law jurisdictions, there is also evidence of labour law's capacity to protect those undertaking unpaid internships. ${ }^{20}$

In the vast majority of Australian cases, liability depended on the employment status of the intern. Yet that legal issue was seldom elaborated. Instead, the parties and the court were simply prepared, either explicitly or implicitly, to accept that there was a contract of employment. However, as Mark Freedland and Nicola Kountouris have suggested, that is a weak foundation upon which to proceed. In a detailed study of personal work relations, they identified 'those engaged in preparatory work, such as "trainees", "apprentices" or "interns", as one of seven major groups of personal work relations that are not contractual or, at least, do not easily fit within the conventional legal analysis of the employment contract. ${ }^{21}$

Conventionally, the law of contract presents two problems in relation to unpaid work experience. ${ }^{22}$ At one level there is the requirement that the parties must have an intention to create legally binding relations. While it is well established that intention is an objective not a subjective matter, ${ }^{23}$ nonetheless it has the potential to be problematic in cases involving unpaid work experience. The issue can be particularly complex when the relevant work

Work Ombudsman v Devine Marine Group Pty Ltd [2014] FCA 1365; Fair Work Ombudsman v Aldred [2016] FCCA 220; Fair Work Ombudsman v AIMG BQ Pty Ltd [2016] FCCA 1024.

17 D-Studio Architects Pty Ltd Enforceable Undertaking [March 2015]; Fair Work Ombudsman v Crocmedia Pty Ltd [2015] FCCA 140.

18 Cossich (n 15); GLS v PLP (n 14); Fair Work Ombudsman v Her Fashion Box Pty Ltd [2019] FCCA 425.

19 Cossich (n 15); Fair Work Ombudsman v Her Fashion Box (n 18).

20 In the UK, Vetta $v$ London Dreams Motion Pictures [2008] UKET 2703377/08 and Hudson v TPG Web Publishing Ltd [2011] UKET 2200565/11, but cf Drozd $v$ Money Matters [2014] NIIT 287_14IT; and in the USA, Glatt v Fox Searchlight Pictures, Inc. 811 F 3d 528, 536 (2016).

${ }_{21}$ See Freedland and Kountouris (n 14) 344 ff esp 347-8.

22 See Andrew Stewart and Rosemary Owens, Exploitation or Experience? The Nature, Prevalence and Regulation of Unpaid Work Experience, Internships and Trial Periods in Australia (University of Adelaide 2013); Stewart and others, 'The Regulation of Internships' (n 6).

${ }_{23}$ Ermogenous v Greek Orthodox Community of SA (Inc) [2002] HCA 8, (2002) 209 CLR 95. 
experience relationship involves more than two parties (for example, a student, a university and a host business; or an intern, an internship agent and a host business; or a person in receipt of welfare payments, the state, a training organization and a host organization). Indeed, Freedland and Kountouris note that in many cases involving work and learning, a third party plays a very large role in prescribing the nature and structure of the relationship, so that it 'would render an analysis in terms of "contractual intention" frankly fictitious'. ${ }^{24}$

Secondly, there is the problem of mutuality. A contract of employment has generally been thought of as bilateral (as opposed to unilateral), and so the idea of mutual obligations regarding future performance is usually treated as essential to its existence. In some Australian cases this has denied the protection of labour law to those undertaking a work trial ${ }^{25}$ or other unpaid work. ${ }^{26}$ The concept of mutuality has been vigorously critiqued, especially in the context of precarious employment in the UK. Nicola Countouris has argued persuasively that the concept was originally focused on the relational aspect of employment, but later remoulded by courts into a prescriptive element and then used to defeat claims relating to forms of precarious employment. ${ }^{27}$ While its resilience in common law cases in the UK relating to employment has hardly been dented, ${ }^{28}$ other jurisdictions have not adhered to it so strictly. However, even in Australia, where the concept has been applied with less rigidity and more akin to the requirement of a wages-work bargain, ${ }^{29}$ it too has been problematic in the context of unpaid internships.

Leaving to one side the important question of whether a contract can be found at all in unpaid work experience, a further dimension to the problem of whether or not the person on unpaid work experience is within the scope of labour law's protection is how that contract is characterized: whether it is a contract of employment or a contract for education, or possibly both.

\footnotetext{
24 Freedland and Kountouris (n 14) 138.

25 Dietrich v Dare (1980) 54 ALJR 388, 390.

26 See Teen Branch Pty Ltd v Brown (1995) 87 IR 308; Redeemer Baptist School Ltd v Glossop [2006] NSWSC 1201; Fair Work Ombudsman, Statement on Findings in Relation to the Fair Work Ombudsman's Investigation of Entities Related to the Church of Scientology, Narconan and Get Off Drugs Naturally (Fair Work Ombudsman 2011).

27 Nicola Countouris, "Uses and Misuses of "Mutuality of Obligations" and the Autonomy of Labour Law' in Alan Bogg, Cathryn Costello, ACL Davies and Jeremias Prassl (eds), The Autonomy of Labour Law (Hart 2015).

28 See eg Carmichael v National Power P/L [1999] ICR 1226, 1229.

29 Automatic Fire Services $v$ Watson (1946) 72 CLR 435.
} 


\subsubsection{The Historical Approach to the Education-Work Boundary in Australia}

Australian labour law, historically, has not marked a strict separation between education and work. Indeed, Australian courts have had no difficulty in understanding that a contract might be simultaneously for education as well as for employment.

This was precisely the approach in Rowe $v$ Capital Territory Health Commission, ${ }^{30}$ which held that nurses undertaking training at a hospital were employees and so entitled to award rates of pay mandated under labour legislation. The evidence revealed that, although treated as 'supernumeraries' and not counted on the ward rosters, the trainee nurses performed a variety of general nursing tasks under the direction of employed staff as part of the service provided to the hospital's patients. If not carried out by the student nurses, the work would have had to be done by the hospital's employees. However, the hospital would not have needed to employ additional staff because experienced staff would do the jobs more quickly and would also be freed from the tasks of supervising trainees.

The hospital sought, unsuccessfully, to persuade the court to treat work that was a 'learning experience' as distinct from work that was 'ward service'. At trial, it was held that there was no mutual exclusivity between the two and the disaggregation of work that was part of training or 'clinical experience' was particularly difficult in the context of lifelong learning at work, especially where there was no specification of quantitative or qualitative measures of when skills are achieved. Justice Keely commented:

It is not correct to assume (either as a matter of logic or language) that the one activity by a student nurse cannot be accurately described as falling within both categories ['clinical experience' and 'ward service']. An activity of an apprentice (or an articled law clerk) may well be both valid practical experience for him [sic] as part of the process of learning his trade (or profession) and yet, at the same time, be fairly described as providing a service to his master or as providing on behalf of his master, a service to the master's client. Nor is it any less a 'service' that the activity of the apprentice has to be supervised by the master (directly or through other employees) or that the 'service' provided by the apprentice or law clerk, either to or on behalf of his master, has to be checked or counter-signed or certified by the master or someone on his behalf. ${ }^{31}$

30 Rowe v Capital Territory Health Commission (1982) 39 ALR 39; and on appeal (1982) 2 IR 27.

31 Rowe (1982) 39 ALR 39, 50. 
In taking this approach, the judge relied on an earlier Australian decision, the Junior Constables Case..$^{32}$ In that case, in response to a similar argument that junior police officers were engaged in training rather than employment, a neat separation between learning, training and work was also rejected. ${ }^{33}$ Justice Morgan identified at least three different interactions between work, education and training: training which did not involve any work; work which involved learning activity; and work that rendered service and did not involve learning. In the Junior Constables Case, he held that the police officers were involved in all three. Nor was it considered important to disaggregate the times when these various work activities might predominate. It was the liability of a junior constable to serve that was relevant, even though they might not serve all the time.

Since Rowe a number of Australian cases have simply accepted that a trainee may have a contract of employment. ${ }^{34}$ Pertinently, there has been a long legislative history in Australia of regulating apprentices under industrial awards. One of the earliest High Court cases, Commonwealth Court of Conciliation and Arbitration; ex parte Whybrow \& $C o,{ }^{35}$ dealt with a dispute over apprentices' wages. No issue was raised as to the appropriateness of regulating the wages of apprentices in awards. That did not necessarily mean, as was assumed in Rowe, that apprentices were considered to be employees. In Whybrow the statutory context was critical. Under the Conciliation and Arbitration Act 1904 (Cth), the important issue was whether the dispute could be classed as 'industrial', and in that regard the Court expressed no doubt. In almost all of these cases the terms of the legislation have been significant. In the Junior Constables Case, the relevant legislation expressly defined 'industrial matters' as not only concerning the rights and obligations of employers and employees, but also of those who proposed to be employers and employees. Nonetheless, what Whybrow and later cases demonstrate is that the Australian regulatory system establishing wages and conditions has long applied to those who are apprentices or trainees. ${ }^{36}$ Indeed, in Rowe Justice Keely took these cases to support the principle of the Junior Constables Case: 'the fact that an apprentice (or other person) is performing duties under a contract the primary purpose of

\footnotetext{
32 Junior Constables Case (1943) 17 SAIR 334.

33 Ibid 346.

34 See Popoovski v Purity Property Services Pty Ltd [2005] AIRC 453; Phung v Advanced Arbor Services Pty Ltd [2010] NSWCA 215.

35 Commonwealth Court of Conciliation and Arbitration; ex parte Whybrow \& Co (1910) 11 CLR 1.

36 See John Heine \& Son Ltd v Pickard (1921) 29 CLR 592; Fletcher $v$ AH McDonald \& Co Pty Ltd (1927) 39 CLR 174; Culbert v Clyde Engineering Co Ltd (1936) 54 CLR 544.
} 
which is to teach that person an occupation, does not prevent that person from being an employee'. ${ }^{37}$

Not surprisingly then, Australian scholars have confidently stated that for the purposes of labour law the contract of apprenticeship has been treated as an employment contract, ${ }^{38}$ and that 'apprentices can ordinarily be regarded as employees' and 'the same is generally true of other trainees who are engaged to perform work while also undergoing a program of training' ${ }^{39}$

One of the factors in Rowe, touched upon only briefly by the Court, was that previously the trainee nurses had been treated as employees of the hospital, with their conditions of work regulated under the relevant award. The hospital then revamped several aspects of the training programme and updated its accompanying documentation. As a consequence, the trainee nurses were subsequently paid a lower 'scholarship allowance'. As the Court found, although the form of the work and training relationship had changed, the substance had not. Owing to this, the appeal judges indicated that Rowe would not necessarily be applicable to a situation where student nurses undertaking a course at another training institution were then placed at the hospital.

Re Crown Employees (Technical Teachers) Award ${ }^{40}$ provided an example analogous to that latter situation. At issue was whether teacher education scholarship holders at institutions of tertiary education were employees to whom the award applied. In particular, there was discussion of whether or not some tasks, such as 'yard duty', undertaken under direction by students assigned to schools for practical teaching amounted to rendering service rather than the receipt of training. All the circumstances of the relationship, including that the trainee teachers spent the greater part of their time undertaking training and only a small part on practical placement, were considered to identify the nature of the relationship. Any control exercised, it was held, was ancillary to the provision of training. In addition, practical teaching was undertaken as part of tertiary education courses and was clearly not part of the teaching service as defined in the Teaching Service Act. The contracts between the Education Department and the trainee teachers were contracts to provide a scholarship during a period of training.

\footnotetext{
Rowe (n 30) 57.

Mark Irving, The Contract of Employment (LexisNexis 2012) [3.43].

Andrew Stewart, Anthony Forsyth, Mark Irving, Richard Johnstone and Shae McCrystal, Creighton and Stewart's Labour Law (6th edn, Federation Press 2016) 265

40 Re Crown Employees (Technical Teachers) Award (1974) 74 AR (NSW) 450.
} [10.41]. 


\subsubsection{The Historical Approach to the Education-Work Boundary in the UK}

In contrast to the approach in Australia, the reasoning in British cases reveals a much clearer dichotomy between employment contracts and contracts of training and education.

Wiltshire Police Authority $v$ Wynn ${ }^{41}$ one of the leading cases in the UK, considered whether a police cadet was an 'employee' under section 30(1) of the Trade Union and Labour Relations Act 1974 and able to claim a remedy for unfair dismissal. In argument it was stated that often service rendered by an employee in training or probationary periods was not very useful to the employer, but this did not nullify the existence of an employment relationship..$^{42}$ However, in deciding the case, Lord Denning applied a test of primary purpose, which emphasized the particularity of the relationship rather than its similarity to 'ordinary' employment:

The distinction between the cases where teaching and learning is the primary purpose - and the cases where the work done is the primary purpose - is helpful in the present context ... [T] hroughout the cadetship the primary purpose is to teach and to learn - not a trade - but as part of general education. It is divided into two phases. In the first year he or she is being given further education. In the second year he or she is there to watch - to see how things are done. We are told that sometimes they help in a minor way: such as holding the tape when there is a measurement to be taken at an accident, or something of that kind. They are giving minor assistance in the work. They are not being taught a trade such as would make them an 'apprentice'. They are not doing work for the employer such as to be under a 'contract of service'. They are neither apprentices nor servants. They are in a class by themselves - police cadets. ${ }^{43}$

Despite the argument from counsel that reliance on old cases was not of assistance in understanding modern work conditions, the court relied on cases from the late eighteenth and early nineteenth centuries concerning whether a pauper was working in a master-servant relationship or as an apprentice. ${ }^{44}$ In $R v$ Inhabitants of Crediton ${ }^{45}$ Justice Taunton provided an overview of a number of

\footnotetext{
Wiltshire Police Authority v Wynn [1981] 1 QB 95.

Ibid 102.

Ibid 109.

$44 \quad R v$ Inhabitants of Laindon (1799) 8 Term Rep 379; $R v$ Inhabitants of Crediton (1831) 2 B \& Ad 493.

${ }_{45} R v$ Inhabitants of Crediton ( $\left.\mathrm{n} 44\right)$.
} 
even earlier authorities, some concerning teacher-scholar relationships, ${ }^{46}$ and others involving a contract of service. ${ }^{47} \mathrm{He}$ concluded:

I take the true distinction in these cases to be this: where teaching on the part of the master, or learning on the part of the pauper is not the primary, but only the secondary object of the parties, that will not prevent (where work is to be done for the master) the contract being considered one of hiring and service ... where teaching and learning are the principal objects of the parties, though there was a service, the contract is to be considered one of apprenticeship. ${ }^{48}$

Horan $v$ Hayhoe, ${ }^{49}$ also relied upon in Wynn, held that a person who had a deed of apprenticeship as a riding groom but also carried out the work of a stable hand, had a contract of apprenticeship rather than a contract of service.

Thus, UK law has long emphasized that an apprenticeship involves a special kind of contract, different from an ordinary contract of employment. In Dunk $v$ George Waller \& Son Ltd ${ }^{50}$ this was illustrated in the context of a decision regarding the appropriate damages to be awarded for breach of a contract of apprenticeship. More recently in Edmonds $v$ Lawson, ${ }^{51}$ involving a pupil barrister, the Court of Appeal of England and Wales described the contract of apprenticeship or any equivalent as:

a synallagmatic contract in which the master undertakes to educate and train the apprentice (or pupil) in the practical and other skills needed to practice a skilled trade (or learned profession) and the apprentice (or pupil) binds himself [sic] to serve and work for the master and comply with all reasonable directions. These mutual covenants are in our judgment cardinal features of such a relationship.

Thus, even though legislation has now often assimilated the apprenticeship to employment, ${ }^{52}$ in the UK the cases are more apt to remind us that the contract of apprenticeship is 'a distinct entity at common law', with its first purpose training, and work as only a second purpose. ${ }^{53}$

$46 \quad$ See eg $R v$ Bilborough (1817) 1 B \& A 115; $R$ v St Mary Kidwelly 2 B \& C 750; $R v$ The Hamlet of Walton Carth 2002 Bott pl 267.

$47 \quad$ See eg $R v$ Hitcham Burr SC 489.

$48 \quad R$ v Inhabitants of Crediton (n 44) 497-8.

$49 \quad$ Horan v Hayhoe [1904] 1 KB 288.

50 Dunk v George Waller \& Son Ltd [1970] 2 QB 163.

51 Edmonds v Lawson [2000] 2 WLR 1091, [30].

52 See eg Employment Rights Act 1966 (UK), s 230(1).

53 See also Wallace v CA Roofing Services Ltd [1996] IRLR 435. See further Simon Deakin and Gillian Morris, Labour Law (6th edn, Hart 2012) 172-4; Freedland and Kountouris (n 14) 137-8. 
Courts and tribunals in the UK have continued to emphasize the primary purpose of the contract, whether education and training or work, when determining whether or not there is an employment relationship. ${ }^{54}$ This has also been evident in cases concerning work experience participants under active labour market programmes (ALMPs). In Daley $v$ Allied Suppliers $L t d,{ }^{55}$ a young person accepted into a government Youth Opportunities Programme was paid a small amount from a sponsoring business, which in turn was reimbursed from the Manpower Services Commission. Although the decision in the case was based on a failure to establish a contract because there was no relevant mutuality, it was noted that even if a contract had been established it would not have been a contract of employment because the primary purpose of the relationship was training. This meant that the trainee had no protection under the Race Relations Act 1976, which at the time covered only those 'employed'.

\subsubsection{The Approaches Compared}

By way of contrast, in the Australian case of Rowe $e^{56}$ Justice Keely rejected an invitation to determine the matter by considering the primary object of the contract, as Lord Denning had done in Wynn. While acknowledging that a distinction between contracts of service and contracts of apprenticeship was critical for some purposes, Justice Keely ruled that it did not follow that it was relevant when determining whether someone was an employee for the purposes of labour standards. In the result, Wynn was distinguished in Rowe on the basis of the different statutory context and because the role outlined in it was largely observational in nature, involving the performance of only some minor tasks.

The statutory context may also have been a significant issue in Daley. In Australia there have been similar rulings that work experience forming part of an ALMP did not involve an employment relationship. For instance, in Pierce v WorkCover/QBE Mercantile Mutual (Dark's Cleaning Services Pty $L t d)^{57}$ an agreement facilitated by a placement agency that the applicant would present for 'work experience' on a two-week work trial was held to indicate 'no common intention of the parties that the relationship entered into ... was that of an employer and employee'. This resulted in no protection for the injury which had been incurred. Similarly in Frattini v Mission Imports ${ }^{58}$ 
a person engaged on a one-week trial of unpaid work experience organized by Jobs Statewide, the provider of an employment training programme for unemployed persons, was held not to be an employee of the host business and so not protected when injured. It is also evident from these cases that it is unlikely that the training or education provider will be held responsible for an injury to a person undertaking work experience..$^{59}$

\subsubsection{Work Experience and the Multi-Factorial Approach to Identifying an Employment Relationship}

The categorization of work experience as a contract of employment or a contract for education is important because, in most legal systems, the employment relationship remains the touchstone for access to most of the protections of labour law. ${ }^{60}$ Examples of labour regulation ignoring it are the exception rather than the rule. Where the categories of worker protected are more extensive, the legislative framework generally achieves this through additions to a basic category of employment. ${ }^{61}$ The issue of identification of an employment relationship has arisen predominantly in cases concerning the distinction between employees and independent contractors. A multi-factorial approach, examining all the relevant facts or circumstances of the case, is now adopted in most jurisdictions, ${ }^{62}$ and in the ILO's Employment Relationship Recommendation. ${ }^{63}$

However, it is notable that the cases characterizing relationships involving both work and education rarely articulate a multi-factorial test. While the Australian cases generally have taken a broad approach, examining all the facts of the case, the UK courts (as we have seen) frequently refer to the importance of defining the 'primary purpose' of the relationship. In the USA, recent cases, while appearing to take a non-exhaustive multi-factorial approach, have also echoed this by indicating that 'the proper question is whether the intern or the employer is the primary beneficiary of the relationship' and emphasizing

\footnotetext{
59 Yi $v$ The Service Arena Pty Ltd [2001] NSWCA 400.

60 See eg US Department of Labor, The Dunlop Commission on the Future of Worker-Management Relations: Final Report (Dunlop Commission 1994) 64, https:// digitalcommons.ilr.cornell.edu/key_workplace/2, accessed 30 March 2021.

${ }_{61}$ See Stewart and McCrystal (n 5).

62 See Nicola Countouris, The Changing Law of the Employment Relationship: Comparative Analyses in the European Context (Ashgate 2007).

${ }_{63}$ ILO Employment Relationship Recommendation, 2006 (No 198), esp arts 9, 11(b). See also ILO, Promoting Employment and Decent Work in a Changing Landscape (Report of the Committee of Experts on the Application of Conventions and Recommendations (articles 19, 22 and 35 of the Constitution), Report III (Part B), International Labour Conference, $109^{\text {th }}$ session, International Labour Office 2020).
} 
that " $[\mathrm{t}]$ he purpose of a bona fide internship is to integrate classroom learning with practical skill development in a real world setting' ${ }^{64}$

Freedland and Kountouris have argued that the 'purpose' of the relationship is important in exposing

the implicit and normally unquestioned reductive analysis of all personal work contracts which would envisage all of them as having the single purpose of providing for the exchange of work for remuneration, the work being provided either in the modality of subordination of the worker or in the modality of the autonomy of the worker. ${ }^{65}$

However, their point merely highlights the fact that a multi-factorial approach to identifying whether or not a work experience arrangement involves an employment relationship will necessarily require consideration of a range of factors different to those used to distinguish employees from independent contractors. One Australian case stands out as an example of this.

Cossich $v$ G Rosetto and Co Pty Ltd ${ }^{66}$ raised the question of whether a person undertaking unpaid work experience was really an employee and so entitled to minimum wages and protection in relation to injury. It involved a student undertaking an Associate Diploma in Wine Marketing, which required 240 hours (equivalent to six weeks' full-time) 'work experience within the wine industry'. The course contained few restrictions on the manner in which the work experience could be gained (whether paid or unpaid, or whether performed on one or several days per week). The student had to locate the work experience herself, there was no liaison between the university and the business, and there were no guidelines as to what the student was expected to do on the placement. The university required only that the student write a report at the completion of her work experience. The applicant spent 21 days with one winemaker, and then approached another with whom she completed the course requirements. Thereafter, she continued to work unpaid for a further eight months, both before and after the completion of her studies and with no change in the substance of what she did, except for an increase in the hours she worked after graduation. She usually worked alone, though with a manager close by, undertaking various tasks, such as serving customers, preparing and maintaining wine displays, moving and unloading cartons of wine, as well as preparing for and attending wine tastings on four evenings. She was paid a small amount, ostensibly to assist with travel expenses. 
Without taking a rigid approach, the magistrate found that the work experience was a 'form of engagement which was little different from full-blown employment' after considering a range of factors. On the length of time of the work experience, he noted: 'By nature work experience ought to be relatively short and little more than a period of acquaintance and understanding of the duties of the work involved. Without attempting to put a limit on it, a year is simply far too long and suggestive of exploitation.' ${ }^{67}$

He linked the relevance of the time factor to the nature of learning and work experience, 'which cannot be permitted as a smokescreen for genuine employment' ${ }^{68}$ : it needs to be objectively defined or quantified, in terms of skills to be observed or demonstrated, and accordingly limited in terms of time. That the work experience was part of a formal course of study was significant, although not conclusive. ${ }^{69}$ That it could be undertaken on a paid or unpaid basis was seen as highlighting that there was no mutual exclusivity between employment and work experience. ${ }^{70}$ Other factors of relevance were the lack of training and the minimal supervision provided by the putative employer; the extent of the work performed and the responsibilities undertaken, which included taking money, using credit cards, operating the till, and being entrusted with basic organization of events like wine tastings; and the expectations regarding the person's competence. As the magistrate concluded, the applicant was actively engaged, not a mere observer, and what she did was of value to the business. ${ }^{71}$ The facts revealed little distinction between the duties of someone on a work experience placement and someone engaged as an employee. ${ }^{72}$ In emphasizing that the true nature of the relationship as revealed by the evidence was what was significant, the magistrate also showed a preparedness to look beyond the words used by parties to describe the relationship: 'the nomenclature ascribed to a position in the agreement cannot be decisive of the nature of the contract'. ${ }^{73}$ The approach in the case specifically eschewed an emphasis on the purpose of the arrangement:

In the matter before me the engagement was undeniably for the purpose of work experience but for reasons to be given ... it was also employment for most if not all of the engagement. There is no good reason why work experience cannot be gained by virtue of employment. It is probably preferable for that purpose but it neces-

\footnotetext{
Ibid [30].

Ibid [36].

Ibid [30].

Ibid.

Ibid [34].

Ibid [35].

73 Citing Kura Yerlo Council Inc (FAI Workers Compensation (SA) (Decision A12/1998).
} 
sarily differs from those engagements where a putative employee takes a passive, untrained role without responsibility. ${ }^{74}$

Finally, in preferring overall the evidence of the applicant, the magistrate adverted to the financial advantage to the business in 'gaining the services of an employee for an outlay well below her award entitlement'.$^{75}$

Cossich is not the only Australian case where a multi-factorial approach has been taken to determine whether an ostensible education or training/ work experience position was in reality disguised employment. In Fair Work Ombudsman v Devine Marine Group Pty Ltd ${ }^{76}$ the multi-factorial approach involved examining all the facts, including: the benefits provided to those undertaking the training (including accommodation, various payments); whether or not the work undertaken was part of a profit-making exercise; the work patterns involved; and the degree of direction and control. Therefore, the case serves as a reminder that a multi-factorial test need not necessarily imply that the set of factors to consider is fixed; the factors reflect the relevant facts of the particular case.

\subsection{CONCLUDING THOUGHTS}

A multi-factorial approach to characterizing a work experience relationship is not without difficulties. As academic commentators have noted, despite broad agreement on a multi-factorial approach in the context of distinguishing an employee from an independent contractor, this test still presents problems. At one level, this is because the courts implement it in different ways. Stewart and McCrystal identify at least three approaches in Australia. ${ }^{77}$ The first is a formalistic approach, giving significant weight to the stated intention of the parties in any contractual documentation. The second approach is a practical reality approach, in which even carefully crafted contracts may be effectively disregarded when they do not reflect the practical reality of the relationship and are thus judged to be a sham. This second approach recognizes that the factors may be manipulated by the more powerful party, which is particularly problematic when a formalistic view is taken. Thirdly, in what may be a variant of the previous approach, some courts have focused on the business reality of the relationship and applied an entrepreneurial test, which involves the determination that there is a fundamental difference between an employee (who serves in the business of another) and an independent contractor (who is an entrepreneur

\footnotetext{
Cossich (n 15) [33].

Ibid [29].

Devine (n 16).

77 Stewart and McCrystal (n 5).
} 
operating their own business, autonomous in their decision-making, and financially self-reliant and chasing a profit).

By analogy, it is not difficult to see that a similar analysis adapting these three approaches could be applied in the cases characterizing relations at the intersection of work and education. For instance, the second approach indicates that, although the parties may label their relationship as 'work experience', perhaps for which there are 'scholarships' or 'certificates' awarded on completion of certain requirements, these labels would only be determinative under a formalistic approach - which now has little support among commentators and judges, who are generally more inclined to focus on the reality of the arrangements. ${ }^{78}$ The third approach would seem to invite consideration of whether there is any fundamental difference between working and learning (and possibly thereby a consideration of the primary purpose as in the UK, or primary benefit of the arrangement as in the USA).

It may be too early still to identify the death of contract as a relevant legal analytical tool in characterizing work relationships, although the steady abandonment by courts of a formalistic approach seems a certain sign that its utility in the field of labour law is diminishing. The factual reality of the relationship is increasingly seen as the relevant thing. Nonetheless, in relation to all three approaches identified here it may still be noted that one of the long-recognized shortcomings of the multi-factorial test is that it does not provide clear guidance to the participants in a work relationship. A multi-factorial approach is even more complex in the context of multilateral arrangements. It remains evident that issues of degree may arise, inevitably requiring a judgement as to whether a work experience relationship is work or education or both. In Devine, Justice White made it clear that was exactly the issue he faced:

I accept that the men did receive some training but it cannot reasonably be regarded as sufficiently detailed or continuing to warrant the description of a course of training ... In my opinion the instruction given to the men was in the form of on the job training of the kind which is common in many workplaces. It cannot reasonably be regarded as an incident of a structured and organised training programme. In particular, the evidence does not indicate that the men spent much time at all being shown techniques, or the manner of working, or in observing others for instructional purposes. $^{79}$

It may be that these words effectively return us to the question of primary purpose or primary beneficiary. However, in the changing world of education it may also be too 'formalistic' to focus on whether work experience is part

78 See Devine (n 16) [90]-[95].

79 Ibid [85]. 
of, or similar to, a structured and organized course of education or training programme, whether offered by a public or private provider, as that does not necessarily indicate incompatibility with an employment relationship. In addition, it may be that these programmes or courses are sometimes themselves a sham involving no real education.

In developing a theory about the effectiveness of labour law, its limits and scope, it is not enough to focus solely on the empirical facts of the work experience relationship itself. The classification of work relationships in order to determine whether a law does (and/or should) apply is a normative exercise. Therefore the multi-factorial approach must be undertaken in conjunction with a consideration of the purposes or goals of the relevant law. ${ }^{80}$

Adopting a frame of analysis similar to that applied by Stewart and McCrystal to the gig economy, ${ }^{81}$ the all-important first question is to identify the laws that should apply to all workers, regardless of their employment status. To this extent, some statutory regulatory schemes need to extend their protections to all workers, and should not be limited to those within the common law concept of 'employee'. These laws should apply to all those engaged in work experience of whichever form (whether as a private arrangement, or an arrangement that is part of a course of education and/or training, or an ALMP arrangement). The principal concern here is recognition of the principle that labour is not a commodity and the right of 'decent work' for all. Laws which are often described as concerned with 'human rights' are the obvious category here. They include protections relating to: equality and anti-discrimination; harassment, bullying and violence at work; freedom of association; freedom from child labour; work safety and health; and limits on working time. ${ }^{82}$ An important and perhaps more difficult issue for policy-makers is not only incorporating these guarantees into law, but also clearly identifying the person or organization with legal responsibility to ensure they are implemented. In so far as the protections are to apply to those at work, in relation to work experience the host employer/business entity seems the obvious entity bearing by default the first responsibility, although it may be both necessary and appropriate to make explicit the liability of other parties, such as education providers.

The issue of the entitlement to minimum wages is a more complex matter. Usually minimum wage standards set out in legislation or agreements are applicable only to employees. As we have noted from the Australian cases, there is no reason why someone undertaking work experience cannot also be an employee. Often this will be the case, and in those situations a minimum

See Rosemary Owens and Joellen Riley, The Law of Work (OUP 2007) 142-3.

Stewart and McCrystal (n 5).

See also ILO, 'Centenary Declaration' (n 3) art IIIB. 
wage should be payable under the law. However, it will not always be the case. Analogously to arguments put by Stewart and McCrystal in the context of the gig economy, it is neither necessary nor sensible nor realistic to consider that all work experience arrangements should attract the minimum wage under labour law. Where work experience is properly characterized as a learning or training experience rather than as employment, it may be appropriate that minimum wage standards do not apply. However, in these cases it should be expected that other legal standards could be indicated as providing a minimum income to the person, specifically in relation to their participation in the work experience (for example, a government welfare payment in the form of a student stipend, or payment for participation in an ALMP). In these cases it should also be expected that states will set out detailed regulations regarding work experience: documentation and standards relating to educational or ALMP placements, including their duration, the hours expected, the specific learning and skills outcomes to be achieved, and the supervision arrangements and mechanisms for assessing the acquisition of skills. It should not be assumed that the involvement of an educational institution or a public employment service is sufficient to ensure that the work experience is attaining learning or training objectives. ${ }^{83}$ Explicit cross-references between the various regulatory regimes (labour law, social security and welfare law, and education law) will serve to bring the requirements to the attention of the full range of persons involved with work experience who deserve clear guidance from the law. However, again following Stewart and McCrystal, a default assumption should be that a person undertaking work experience is an employee. The burden of proving the relationship is exempted from labour standards relating to pay and governed by an alternative regulatory regime must lie with other relevant actors (host businesses, educational institutions or agency providers) involved in the relationship. In this way the law should ensure that there are no gaps in labour law's protection of those undertaking work experience.

83 See Stewart and others, 'The Regulation of Internships' (n 6) ch 11. 